\title{
WPLYW ZAOSTRZONYCH KRYTERIÓW OCENY ZDOLNOŚCI KREDYTOWEJ OSÓB FIZYCZNYCH NA LICZBĘ ZAWIERANYCH UMÓW KREDYTÓW HIPOTECZNYCH
}

\section{Wstęp}

Analizując rynek kredytów hipotecznych w Polsce w ostatnich latach, można było zauważyć, iż przeżywał on dynamiczny rozwój. Tego rodzaju kredyt stał się najczęstszym źródłem finansowania nieruchomości, zwłaszcza nieruchomości mieszkaniowych. Jednakże kryzys finansowy lat 2007-2009 spowodował konieczność zaostrzenia kryteriów oceny zdolności kredytowej.

Celem niniejszej pracy jest ocena zmiany polityki kredytowej banków, której najbardziej zauważalnym efektem był spadek liczby udzielanych kredytów hipotecznych. Autorzy podjęli się również próby predykcji ilościowych skutków wspomnianych zmian polityki kredytowej na lata 2013-2020 oraz określili ich znaczenie zarówno dla klientów, jak i dla banków.

\section{Istota zdolności kredytowej i analiza czynników ją determinujących}

Warunkiem uzyskania kredytu hipotecznego jest posiadanie przez kredytobiorcę zdolności kredytowej. Prawo bankowe definiuje zdolność kredytową jako ,zdolność do spłaty zaciągniętego kredytu wraz z odsetkami w terminach określonych w umowie ${ }^{1 "}$. Wpływ na jej wysokość wywierają, m.in. dochody i zobowiązania, obciążenia kredytowe, okres kredytowania, oprocentowanie kredytu, system spłat kredytu i jego waluta.

* Doktorantka, Instytut Finansów, Wydział Ekonomiczno-Socjologiczny, Uniwersytet Łódzki.

** Doktorant, Instytut Finansów, Wydział Ekonomiczno-Socjologiczny, Uniwersytet Łódzki.

${ }^{1}$ Ustawa z dnia 29 sierpnia 1997 r. - Prawo bankowe, tj: Dz.U. z 2002 r. nr 72 , poz. 665 , ze zm., art. 70 . 
Pierwszy z paramentów - dochody i zobowiązania, stanowi jeden z głównych czynników decydujących o zdolności kredytowej. Dochód, który uwzględniany jest $\mathrm{w}$ analizie, musi mieć charakter stały i musi być stabilny w czasie. Do zobowiązań zalicza się nie tylko zobowiązania kredytowe i finansowe, ale także koszty ponoszone przez klienta na utrzymanie domu i rodziny ${ }^{2}$. Po odjęciu od dochodów stałych zobowiązań klienta, otrzymujemy nadwyżkę finansową kredytobiorcy, z której klient będzie mógł spłacać raty kredytu hipotecznego. Jeśli nadwyżka ta okaże się wystarczająca, kredyt hipoteczny zostanie przyznany. Im wyższa wysokość dochodu pomniejszonego o obciążenia, tym wyższa możliwa do otrzymania kwota kredytu ${ }^{3}$.

Bank, przy ocenie zdolności kredytowej, winien brać również pod uwagę sumę miesięcznych rat kredytowych klienta tak, by zachować odpowiednią relację między wysokością obciążeń kredytowych a wysokością osiąganego dochodu. Dopuszczalny poziom zadłużenia reguluje Rekomendacja $\mathrm{T}$.

Sposobem na zwiększenie zdolności kredytowej jest wydłużenie okresu kredytowania. Dłuższy okres kredytowania wpływa na zmniejszenie wysokości raty, stąd też większa kwota kredytu możliwa do udzielenia potencjalnemu kredytobiorcy. Negatywną konsekwencją wydłużenia okresu kredytowania jest jednak zwiększenie kosztu odsetkowego w całym okresie kredytowania ${ }^{4}$.

Podobny wpływ na zdolność kredytową ma wybór systemu spłat kredytu $\mathrm{w}$ formie rat równych zamiast rat malejących. W przypadku rat równych, rata kredytu, zwłaszcza na początku okresu spłacania, jest niższa niż w przypadku rat malejących. Taka też rata brana jest do badania zdolności kredytowej $\mathrm{w}$ momencie podejmowania decyzji o udzieleniu kredytu. Stąd zdolność kredytowa przy ratach równych okazuje się być wyższa ${ }^{5}$.

Oprocentowanie kredytu wpływa na zdolność kredytową w ten sposób, że im wyższe oprocentowanie, tym niższa zdolność kredytowa ${ }^{6}$.

${ }^{2}$ G. Główka, Mieszkaniowy kredyt hipoteczny w Polsce, Szkoła Główna Handlowa w Warszawie, Warszawa 2010, s. 53-54.

3 Z. Dobosiewicz, Kredyt hipoteczny. Poradnik, Wydawnictwo DIFIN, Warszawa 2010, s. 20.

${ }^{4}$ G. Główka, Mieszkaniowy kredyt hipoteczny w Polsce, op. cit., s. 54-55.

${ }^{5}$ Ibidem, s. 55.

${ }^{6}$ Z. Dobosiewicz, Kredyt hipoteczny. Poradnik, op. cit., s. 21. 
Waluta kredytu również decyduje o wysokości maksymalnej zdolności kredytowej. Wyższa zdolność kredytowa jest przy kredytach złotowych niż przy kredytach walutowych. Bank, udzielając kredytu w walucie obcej, musi bowiem zabezpieczyć się przed ryzykiem zmiany kursu walutowego ${ }^{7}$.

\section{Przegląd rekomendacji wprowadzanych przez KNF}

W kontekście zaostrzenia kryteriów oceny zdolności kredytowej osób fizycznych, warto wspomnieć o dokumentach wystosowanych do banków przez Komisję Nadzoru Finansowego - Rekomendacji T oraz Rekomendacji S.

Rekomendacja $\mathrm{T}$ odnosi się przede wszystkim do oceny zdolności kredytowej klientów. Bank powinien uwzględniać wymóg stabilności i ostrożności, ujmując $\mathrm{w}$ zasadach polityki kredytowej długoterminową perspektywę zarządzania ryzykiem i wrażliwość na zmiany warunków otoczenia oraz oddziaływanie na poziom ryzyka kredytowego poprzez właściwy dobór klientów. Zwrócenie uwagi na powyższe kwestie wynika, zdaniem UKNF, z praktyk stosowanych przez banki w zakresie akceptacji ryzyka, odbiegających często od tak zdefiniowanych wymogów i prowadzących do nadmiernej ekspozycji na ryzyko. W szczególności podkreśla się brak obiektywizmu i niezbędnego konserwatyzmu w zakresie parametrów przyjmowanych do oceny zdolności i wiarygodności kredytowej klientów. Dopuszczanie do akceptowania nadmiernego obciążenia dochodu klientów z tytułu obsługi zadłużenia jest kolejnym przykładem nadmiernego liberalizmu zasad polityki kredytowej. Szczególnie niepokojąca jest praktyka wobec grup klientów o najniższych dochodach, które przeznaczają największą część dochodów na zaspokojenie potrzeb podstawowych ${ }^{8}$.

Zgodnie $\mathrm{z}$ założeniami Rekomendacji $\mathrm{T}$ maksymalny poziom relacji wydatków związanych z obsługą zobowiązań kredytowych do średnich dochodów netto osiąganych przez potencjalnych kredytobiorców nie powinien być wyższy niż 50\% dochodów netto dla klientów detalicznych, których płaca nie przekracza poziomu przeciętnego wynagrodzenia w gospodarce. Bądź też, jeżeli zarobki przekraczają poziom przeciętnego wynagrodzenia w gospodarce,

\footnotetext{
${ }^{7}$ Ibidem, s. 59.

8 Rekomendacja $\mathrm{T}$ dotycząca dobrych praktyk w zakresie zarządzania ryzykiem detalicznych ekspozycji kredytowych, Komisja Nadzoru Finansowego, Warszawa, luty 2010, s. 2-3.
} 
maksymalna kwota zobowiązań kredytowych nie powinna przekroczyć $65 \%$ osiąganego dochodu netto. Ponadto w przypadku, gdy kredytobiorca będzie chciał zadłużyć się w obcej walucie na okres powyżej 5 lat, będzie zobligowany do wpłaty $20 \%$ wkładu własnego, zaś w okresie kredytowania krótszym niż 5 lat, wkład własny powinien wynosić $10 \%{ }^{9}$.

W 2011 r. w ramach Rekomendacji S wprowadzono obostrzenia co do długości okresu kredytowania. Dokonując oceny zdolności kredytowej, według Urzędu Komisji Nadzoru Finansowego, w przypadku, gdy przewidywany okres spłaty ekspozycji jest dłuższy niż 25 lat, bank powinien przyjmować w procesie oceny zdolności kredytowej okres spłaty ekspozycji wynoszący 25 lat. Ponadto jeżeli okres spłaty kredytu wykracza poza wiek uprawniający do nabycia uprawnień emerytalnych, bank powinien uwzględnić w ocenie zdolności kredytowej prawdopodobną zmianę poziomu dochodów kredytobiorcy po nabyciu uprawnień emerytalnych ${ }^{10}$.

\section{Znaczenie zaostrzenia polityki kredytowania dla liczby nowo udzielanych kredytów mieszkaniowych}

Zaostrzanie kryteriów oceny zdolności kredytowej w odniesieniu do kredytów hipotecznych wywiera istotny wpływ na liczbę zawieranych umów kredytowych. Dane dotyczące liczby udzielanych kredytów mieszkaniowych w ujęciu rocznym i kwartalnym opisane zostały na wykresie 1 . i wykresie 2 .

W analizowanym okresie (2008-2012), największa liczba umów kredytowych zawarta została w 2008 r. Rok ten należał do okresu ekspansji kredytowej banków. Rok 2009 charakteryzował się już znacznym spadkiem liczby nowo podpisanych umów, który wynosił ponad 34\% w stosunku do roku 2008. Sytuacja ta była silnie skorelowana $\mathrm{z}$ globalnym kryzysem finansowym, skutkującym podwyższaniem marż przez banki oraz zaostrzeniem kryteriów oceny zdolności kredytowej ${ }^{11}$.

\footnotetext{
${ }^{9}$ Ibidem, s. 23.

10 Rekomendacja S dotycząca dobrych praktyk w zakresie zarządzania ekspozycjami kredytowymi finansującymi nieruchomości oraz zabezpieczonymi hipotecznie, Komisja Nadzoru Finansowego, Warszawa styczeń 2011, s. 22.

${ }^{11}$ Ogólnopolski raport o kredytach mieszkaniowych i cenach transakcyjnych nieruchomości, Amron, ZBP, marzec 2010, s. 3,7.
} 
Wykres 1. Liczba nowo podpisanych umów o kredyt mieszkaniowy rocznie w latach 2008-2011 (w sztukach)

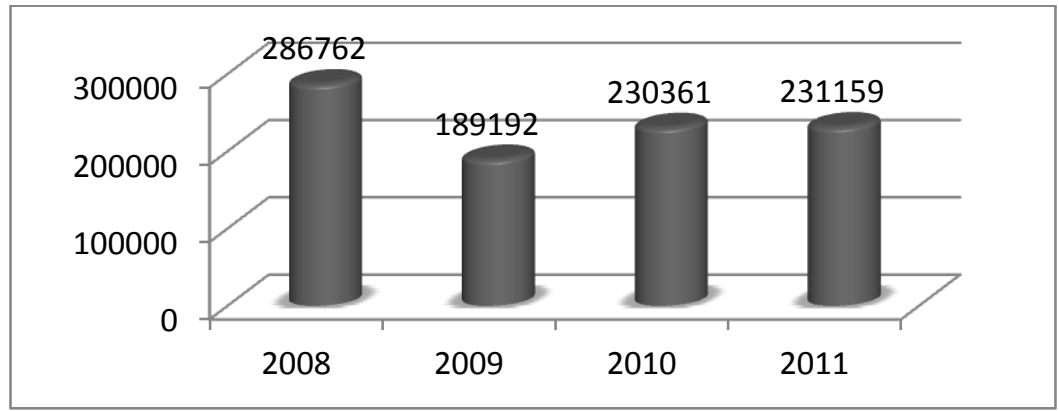

Źródło: Ogólnopolski raport o kredytach mieszkaniowych $i$ cenach transakcyjnych nieruchomości, nr 4/2011, Amron, ZBP, luty 2012, s. 7.

Wykres 2. Liczba nowo podpisanych umów o kredyt mieszkaniowy kwartalnie w latach 2010-2012 (w sztukach)

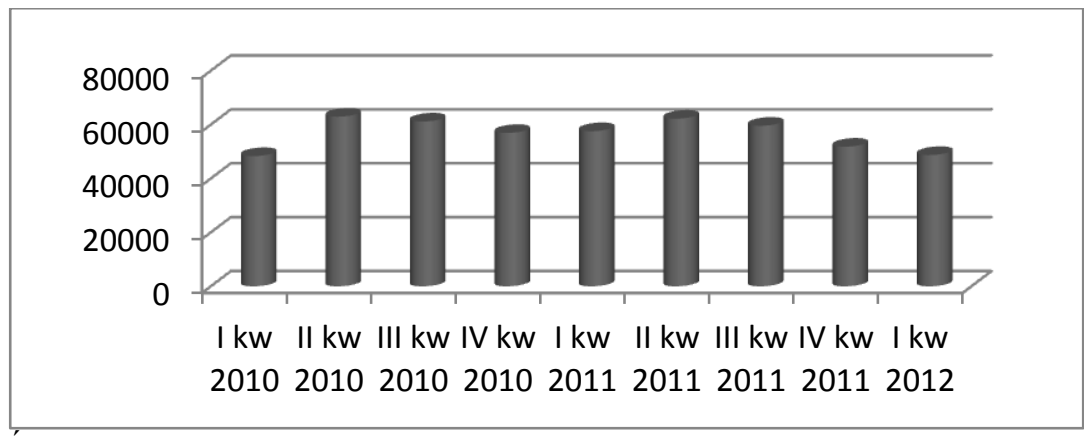

Źródło: Ogólnopolski raport o kredytach mieszkaniowych $i$ cenach transakcyjnych nieruchomości, $\mathrm{nr}$ 4/2011, Amron, ZBP, luty 2012, s. 7.

W roku 2010 bankom udało się nieco odbudować utraconą pozycję i zwiększyć liczbę zawieranych umów o kredyty hipoteczne. Wynikało to, m.in. $\mathrm{z}$ rozpowszechnienia się rządowego programu „Rodzina na swoim”. Zwiększył się również udział kredytów udzielanych $w$ walucie krajowej, a ograniczeniu uległa liczba podpisywanych umów w walutach obcych, zwłaszcza we frankach szwajcarskich. Ograniczenie liczby umów w walutach obcych wynikało, m.in. z zaostrzenia kryteriów oceny zdolności kredytowej i konieczności posiadania większej zdolności kredytowej 
w porównaniu $\mathrm{z}$ klientami ubiegającymi się o kredyt $\mathrm{w}$ walucie krajowej $^{12}$.

Poprawa sytuacji na rynku kredytów hipotecznych okazała się krótkotrwała, gdyż w drugiej połowie 2010 r. widoczne było już załamanie tendencji wzrostowej $w$ liczbie zawieranych umów kredytowych. Na poziom akcji kredytowej w III i IV kwartale $2010 \mathrm{r}$. $\mathrm{w}$ dużym stopniu wpłynęło zaostrzenie przez banki polityki kredytowej, w związku z koniecznością dostosowania jej do wymogów Rekomendacji $\mathrm{T}^{13}$.

Początek roku 2011 przyniósł niewielki wzrost liczby zawieranych umów (w 2011 r. odnotowano przyrost zawieranych umów w odniesieniu do roku poprzedniego jedynie o ok. 0,35\%). Jednakże, począwszy od II kwartału 2011 do I kwartału 2012 r. włącznie, zarysowała się wyraźna tendencja spadkowa wolumenu podpisywanych umów kredytowych. Kolejne zaostrzenie kryteriów oceny zdolności kredytowej, wynikające z nowelizacji Rekomendacji S i konieczność dostosowania procedur bankowych do jej wymogów wywarły istotny wpływ na liczbę zawieranych umów, ograniczając tym samym dostęp osób fizycznych do kredytów mieszkaniowych. Wynikało to również ze stopniowego wygaszania programu „Rodzina na swoim" ${ }^{\text {"14 }}$. Ponadto wycofanie w 2012 r. przez większość banków z oferty kredytów walutowych, które dotychczas cieszyły się dużą popularnością, przyczyniło się do spadku ilości udzielanych kredytów. Liczba zawartych umów kredytowych w I kwartale 2012 r. osiągnęła poziom najniższy od początku $2010 \mathrm{r}^{15}$ Jak wskazują dane publikowane przez Narodowy Bank Polski, już na początku pierwszego kwartału 2012 roku widać było wyraźnie, że na zmianę polityki kredytowej banków miały wpływ przede wszystkim dwa zjawiska. Po pierwsze, podwyższenie wymaganego wkładu własnego kredytobiorcy $\mathrm{w}$ inwestycji oraz poziomu wymaganych zabezpieczeń. Po drugie, wycofanie ofert kredytów walutowych, jak i zaostrzenie

\footnotetext{
${ }^{12}$ Ogólnopolski raport o kredytach mieszkaniowych i cenach transakcyjnych nieruchomości, nr 4/2010, Amron, ZBP, grudzień 2010, s. 4-7.

${ }^{13}$ Ibidem, s. 4-7.

${ }^{14}$ Ogólnopolski raport o kredytach mieszkaniowych i cenach transakcyjnych nieruchomości, nr 4/2011, Amron, ZBP, luty 2012, s. 4-5.

${ }^{15}$ Ogólnopolski raport o kredytach mieszkaniowych i cenach transakcyjnych nieruchomości, nr 1/2012, Amron, ZBP, maj 2012, s. 4-5.
} 
zasad kalkulacji zdolności kredytowej, w związku z wdrożeniem nowych przepisów Rekomendacji $\mathrm{S}^{16}$.

Zgodnie z prognozami Urzędu Komisji Nadzoru Finansowego przewidywane przez banki poziomy należności $\mathrm{z}$ tytułu udzielonych kredytów mieszkaniowych na koniec 2012 r. powinny wzrosnąć w stosunku do końca 2011 r. zaledwie o 2\% (czyli o około 6 mld zł), podczas gdy w 2011 r. poziom należności mieszkaniowych wzrósł w bankach o 52 mld zł, przy sprzedaży nowych kredytów na poziomie 60 mld zł. Prognozowany wzrost należności w bilansach banków na koniec 2012 roku wynosi tylko 2\%, co oznacza konieczność drastycznego wstrzymania udzielania kredytów mieszkaniowych przez banki w II połowie roku. Tym samym w 2012 roku należy oczekiwać poważnych spadków sprzedaży, związanych przede wszystkim z naciskiem regulatorów oraz z niedostatecznym poziomem depozytów i innych funduszy, co w konsekwencji nie pozwoli dalej rozwijać się kredytom mieszkaniowym ${ }^{17}$.

\section{Badanie własne potwierdzające zaostrzenie kryteriów oceny zdolności kredytowej}

W oparciu o badanie własne zweryfikowano, czy nakładane przez KNF wytyczne co do procesu oceny zdolności kredytowej wdrażane są przez banki i czy rzeczywiście zaostrzają one politykę kredytowania, a przez to powodują zmniejszenie liczby zawieranych umów kredytowych. Badanie przeprowadzono na podstawie danych uzyskanych z losowo wybranej próby 1.884 wniosków kredytowych. Były to wnioski osób fizycznych ubiegających się o uzyskanie kredytu hipotecznego w latach 2009-2012 w jednym z banków działających na rynku w Polsce.

Pierwszym etapem badania było wykonanie czterech modeli ekonometrycznych (dla każdego roku z przedziału 2009-2012), które wskazać miały jakie czynniki i w jakim stopniu wpływają na maksymalną posiadaną przez klientów zdolność kredytową. Jako zmienne objaśniające wybrano:

- Okres kredytowania w miesiącach (t).

- Oprocentowanie kredytów (stpr).

16 Sytuacja na rynku kredytowym. Wynik ankiety do przewodniczacych komitetów kredytowych. I kwartat 2012, NBP, Warszawa, styczeń 2012, s. 67.

${ }^{17}$ Kredyt i trendy, Biuro Informacji Kredytowej, czerwiec 2012, s. 17-28. 
- Wskaźnik będący ilorazem łącznych obciążeń kredytowych, włącznie z ratą wnioskowanego kredytu do dochodu (r_d).

- Łączny dochód klientów pomniejszony o łączne obciążenia w zł (d_or).

- Walutę kredytu, rozróżniając kredyt w walucie polskiej i kredyt w walucie obcej, jako zmienną zerojedynkową, gdzie „1” - kredyt w PLN, ,0”- kredyt walutowy (p_1w_0).

- System spłat rat kapitałowo-odsetkowych, w podziale na raty równe i malejące, jako zmienną zerojedynkową, tj. „1” - system spłat w formie rat równych, „,0" - raty malejące (r_1m_0).

Założono, iż wraz z wydłużaniem okresu kredytowania oraz łącznych dochodów pomniejszonych o obciążenia, zdolność kredytowa będzie rosnąć. Na wyższą kwotę kredytu winni również liczyć klienci, którzy wnioskują o kredyt $\mathrm{w}$ walucie polskiej i z systemem spłat w formie rat równych. Zdolność kredytowa będzie spadać wraz ze wzrostem oprocentowania kredytu oraz przy wyższym wskaźniku, będącym ilorazem łącznych obciążeń kredytowych (włącznie $\mathrm{z}$ ratą wnioskowanego kredytu) do dochodu. Wyniki jakie uzyskano, czyli wpływ poszczególnych czynników na poziom zdolności kredytowej, zostały zestawione zbiorczo $w$ tabeli 1 . Oszacowane modele charakteryzują się wysokim objaśnieniem zmiennej objaśniającej przez zmienność zmiennych objaśnianych (współczynniki determinacji na poziomie 91-96\%). Reszty modelu mają rozkład normalny, wszystkie zmienne objaśniające okazały się istotne statystycznie, a kierunki znaków przy zmiennych są zgodne $\mathrm{z}$ oczekiwaniami. Błąd standardowy reszt mieści się w przedziale ok. 60 000-76 500 zł.

$\mathrm{Z}$ danych zawartych $\mathrm{w}$ tabeli 1wynikają następuje postacie funkcyjne:

- $\operatorname{rok} 2009$ :

$\mathrm{mzk}_{2009}=-18880,20+648,00 \mathrm{t}_{2009(\mathrm{ta}=15,14)^{-}}-30191,90 \mathrm{stpr}_{2009(\mathrm{t} \alpha=-6,61)^{-}}$ $49983,70 r_{-} \mathrm{d}_{2009(\mathrm{t} \alpha=-1,82)}+67,09 \mathrm{~d} \_$or $2009(\mathrm{t} \alpha=82,47)+104963,00 \mathrm{p} \_1_{2009(\mathrm{t} \alpha=}$ ${ }_{6,76)}+79695,10 \mathrm{r} \_1_{2009(\mathrm{ta}=6,91)}$

- $\operatorname{rok} 2010$ :

$\mathrm{mzk}_{2010}=-135274,00+654,77 \mathrm{t}_{2010(\mathrm{t} a=16,94)^{-}}-25989,30 \mathrm{stpr}_{2010(\mathrm{ta}=-5,00)^{-}}$ 67080,6_d $\mathrm{d}_{2010(\mathrm{t} \alpha=-1,96)}+92,20 \mathrm{~d} \_\mathrm{or}_{2010(\mathrm{t} \alpha=91,64)}+74689,90 \mathrm{p} \_1_{2010(\mathrm{t} \alpha=3,43)}+$ 107827,00_1 2010(to $=10,43)$

- $\operatorname{rok} 2011$ : 
$\mathrm{mzk}_{2011}=-70780,30+839,37 \mathrm{t}_{2011(\mathrm{t} \alpha=17,63)^{-}}-37553,20 \mathrm{stpr}_{2011(\mathrm{t} \alpha=-5,89)^{-}}$

$103517,00 \mathrm{r} \_\mathrm{d}_{2011(\mathrm{t} \alpha=-2,87)}+74,84 \mathrm{~d} \_0 r_{2011(\mathrm{t} \alpha=68,64)}+127146,00 \mathrm{p} \_1_{2011(\mathrm{t} \alpha=}$

$5,63)+87663,50 r_{-} 1_{2011(t \alpha=7,10)}$

- $\quad$ rok 2012:

$\mathrm{mzk}_{2012}=-51499,30+612,85 \mathrm{t}_{2012(\mathrm{t} \alpha=17,57)}-29444,30 \mathrm{stpr}_{2012(\mathrm{t} a=-3,88)^{-}}$

$76733,60 \mathrm{r} \_\mathrm{d}_{2012(\mathrm{t} \alpha=-2,38)}+65,19 \mathrm{~d} \_\mathrm{or}_{2012(\mathrm{t} a=60,49)}+160395,00 \mathrm{p} \_1_{2012(\mathrm{t} \alpha=}$ ${ }_{6,08)}+56532,10 \_1_{\text {2012(to }=5,32)}$

Tabela 1. Zbiorcze zestawienie wyników dla lat 2009-2012

\begin{tabular}{|c|c|c|c|c|}
\hline Rok & 2009 & 2010 & 2011 & 2012 \\
\hline Liczebność próby & 503 & 451 & 512 & 418 \\
\hline $\begin{array}{l}\text { Współczynnik dla } \\
\text { stałej }\end{array}$ & $-18880,20$ & $\begin{array}{r}-135 \\
274,00\end{array}$ & $-70780,30$ & $-51499,30$ \\
\hline $\begin{array}{l}\text { Współczynnik dla } \\
\text { zmiennej t }\end{array}$ & 648,00 & 654,77 & 839,37 & 612,85 \\
\hline $\begin{array}{l}\text { Współczynnik dla } \\
\text { zmiennej stpr }\end{array}$ & $-30191,90$ & $-25989,30$ & $-37553,20$ & $-29444,30$ \\
\hline $\begin{array}{l}\text { Współczynnik dla } \\
\text { zmiennej r_d }\end{array}$ & $-49983,70$ & $-67080,60$ & $-103517,00$ & $-76733,60$ \\
\hline $\begin{array}{l}\text { Współczynnik dla } \\
\text { zmiennej d_or }\end{array}$ & 67,09 & 92,20 & 74,84 & 65,19 \\
\hline $\begin{array}{l}\text { Współczynnik dla } \\
\text { zmiennej p_1w_0 }\end{array}$ & 104963,00 & 74689,90 & 127146,00 & 160395,00 \\
\hline $\begin{array}{l}\text { Współczynnik dla } \\
\text { zmiennej r_1m_0 }\end{array}$ & 79695,10 & 107827,00 & 87663,50 & 56532,10 \\
\hline JB & 4,50 & 4,55 & 5,04 & 4,90 \\
\hline $\mathrm{R}^{2}$ & $93,99 \%$ & $96,01 \%$ & $91,68 \%$ & $94,20 \%$ \\
\hline $\begin{array}{l}\text { Błąd standardowy } \\
\text { reszt }\end{array}$ & 76509,58 & 59967,83 & 76487,50 & 66436,70 \\
\hline
\end{tabular}

Źródło: Opracowanie własne.

Z powyższych modeli wywnioskować można, iż wydłużanie okresu kredytowania o jeden miesiąc powodowało wzrost zdolności kredytowej odpowiednio w 2009 r. o ok. 648 zł , w 2010 r. o ok. 655 zł, w 2011 r. o ok. 839 zł, a w roku 2012 o ok. 613 zł, ceteris paribus. Na przestrzeni lat 2009-2011, z każdym kolejnym rokiem, wzrost okresu kredytowania o jeden miesiąc powodował zatem większy przyrost zdolności kredytowej niż w roku poprzednim. Zmiana widoczna była w roku 2012, gdzie wydłużenie okresu kredytowania powodowało zwiększenie zdolności kredytowej, lecz na 
poziomie niższym niż w poprzednich latach. Nieco odmienna sytuacja występowała w przypadku oprocentowania kredytu. Wzrost stopy procentowej o 1 punkt procentowy powodował obniżenie kwoty kredytu przeciętnie o 30192 zł w 2009 r., o 25989 zł w 2010 r., o ok. 37553 zł w 2011 r., a w 2012 średnio o 29444 zł, przy pozostałych czynnikach niezmienionych. W latach 2009-2011, coraz większym spadkom zdolności kredytowej towarzyszył również wzrost wskaźnika, będącego ilorazem łącznych obciążeń kredytowych (wraz $\mathrm{z}$ ratą wnioskowanego kredytu) do dochodu. W 2012 r. obniżenie zdolności kredytowej było mniejsze, tj. wzrost wspomnianego wskaźnika o 1 punkt powodował obniżenie zdolności kredytowej o ok. 76734 zł, ceteris paribus. Najbardziej istotna statystycznie okazała się jednak zmienna opisująca wysokość dochodu pomniejszonego o obciążenia. Wzrost poziomu tego wskaźnika o $100 \mathrm{zł}$, powodował wzrost maksymalnej zdolności kredytowej średnio o ok. 7500 zł na przestrzeni badanych lat, przy czym największy wzrost zdolności pod wpływem wzrostu dochodu po odjęciu obciążeń widoczny był w 2010 roku (o ok. 9200 zł). Na wyższą kwotę kredytu liczyć mogli również klienci ubiegający się o kredyt $\mathrm{z}$ systemem spłat $\mathrm{w}$ formie rat równych lub kredyt, którego walutą był złoty polski. Zaciągając kredyt w walucie krajowej, klient mógł otrzymać kredyt wyższy o ok. 105000 zł w 2009 r., o ok. 75000 zł w 2010 r., o ok. 127000 zł w 2011 r. i o ok. 160000 zł w 2012 r. niż w przypadku kredytu walutowego. Maksymalna zdolność kredytowa przy kredycie $\mathrm{z}$ systemem spłat $\mathrm{w}$ formie rat równych jest wyższa $\mathrm{w}$ porównaniu $\mathrm{z}$ systemem spłat $\mathrm{w}$ formie rat malejących, odpowiednio o ok. 80000 zł w 2009 r., o ok. 108000 zł w 2010 r., o ok. 88000 zł w 2011 r. i o ok. $56500 \mathrm{zł} \mathrm{w} 2012$ r.

Kolejnym etapem badania własnego było określenie wpływu zmian polityki kredytowania, wprowadzanych kolejno w latach 20092012, na sposób postrzegania maksymalnej zdolności kredytowej. Omawiany wpływ wyznaczono, porównując zdolność kredytową grupy klientów (tych samych, co w przypadku szacowania powyższych modeli ekonometrycznych), którzy otrzymali kredyt w latach 2009-2011 ze zdolnością, jaką posiadaliby przy pierwotnych parametrach ( $\mathrm{tj} . \mathrm{z}$ dnia podejmowania decyzji o udzieleniu kredytu), wyznaczoną jednak modelem obowiązującym w roku 2012.

Otrzymano następujące zależności:

- Maksymalna zdolność kredytowa z 2012(2009) $=0,85 \mathrm{x}$ maksymalna zdolność kredytowa z 2009.

- Maksymalna zdolność kredytowa $\mathrm{z}$ 2012(2010) $=0,79 \mathrm{x}$ maksymalna zdolność kredytowa z 2010. 
- Maksymalna zdolność kredytowa $\mathrm{z}$ 2012(2011) $=0,88 \mathrm{x}$ maksymalna zdolność kredytowa z 2011.

Wyniki te wskazują, iż klient, który otrzymał kredyt w 2009 r. przy kryteriach oceny zdolności kredytowej obowiązujących w 2012 r., miałby aż o 15\% niższą zdolność kredytową. Podobnie było w roku 2010, w którym klient, zakładając iż w 2010 r. posiadał zdolność kredytową na kwotę 100000 zł, składając wniosek w 2012 r., miałby szansę na kredyt nie wyższy niż 79000 zł przy tożsamych parametrach kredytowych i dochodowych. Zmiany w podejściu do badania zdolności kredytowej w roku 2012 w stosunku do 2011 r. charakteryzują się obniżeniem zdolności kredytowej o $12 \%$.

Wyraźna tendencja do zaostrzania kryteriów oceny zdolności kredytowej i obniżania jej poziomu wskazuje, iż prawdopodobnie tendencja ta utrzymywać się będzie w kolejnych latach. Jednakże próba badawcza na bazie 4 lat jest niewystarczająca, biorąc pod uwagę liczbę szacowanych parametrów, by móc dokonać modelowania, a w dalszej kolejności prognozowania zakresu i stopnia dalszego zaostrzania polityki kredytowej.

\section{Podsumowanie}

Przeprowadzona $\mathrm{w}$ niniejszej pracy analiza zmian polityki kredytowania w latach 2009-2012 potwierdza zaostrzenie kryteriów oceny zdolności kredytowej, skutkujące zmniejszeniem liczby zawieranych umów o kredyty hipoteczne. Biorąc pod uwagę, że głównym przedmiotem działalności i kluczowym źródłem dochodu banków jest udzielanie kredytów, niemożliwym wydaje się ograniczanie prowadzonej akcji kredytowej w kolejnych latach. Za takim stanowiskiem przemawia brak alternatywnego źródła dochodu. Zmiany w polityce gospodarczej kraju, w tym m.in. podnoszenie podatków konsumpcyjnych, czy też wydłużenie wieku emerytalnego, będą miały negatywny wpływ na przyszłe dochody społeczeństwa i poziom oszczędności. To z kolei uniemożliwi bankom poszerzenie zakresu prowadzonej działalności, chociażby inwestycyjnej, poza udzielaniem kredytów. Oznacza to, że w perspektywie najbliższych lat sektor bankowy będzie musiał powrócić do prowadzenia aktywnej akcji kredytowej. Ponadto mało prawdopodobne jest, by zakup nieruchomości mieszkaniowych finansowany był wyłącznie środkami własnymi nabywców, co potwierdza tylko tezę, iż kryteria oceny zdolności kredytowej będą musiały być nieco złagodzone, przy utrzymaniu ścisłego monitoringu jakości portfela kredytowego. 


\section{Bibliografia}

1. Ustawa z dnia 29 sierpnia 1997 r. - Prawo bankowe, tj: Dz.U. z 2002 r. nr 72, poz. 665, ze zm.

2. Rekomendacja $\mathrm{T}$ dotycząca dobrych praktyk $\mathrm{w}$ zakresie zarządzania ryzykiem detalicznych ekspozycji kredytowych, Komisja Nadzoru Finansowego, Warszawa, luty 2010.

3. Rekomendacja S dotycząca dobrych praktyk w zakresie zarządzania ekspozycjami kredytowymi finansującymi nieruchomości oraz zabezpieczonymi hipotecznie, Komisja Nadzoru Finansowego, Warszawa, styczeń 2011.

4. Dobosiewicz Z., Kredyt hipoteczny. Poradnik, Wydawnictwo DIFIN, Warszawa 2010.

5. Główka G., Mieszkaniowy kredyt hipoteczny w Polsce, Szkoła Główna Handlowa w Warszawie, Warszawa 2010.

6. Kredyt i trendy, Biuro Informacji Kredytowej, czerwiec 2012.

7. Ogólnopolski raport o kredytach mieszkaniowych $i$ cenach transakcyjnych nieruchomości, Amron, ZBP, marzec 2010.

8. Ogólnopolski raport o kredytach mieszkaniowych $i$ cenach transakcyjnych nieruchomości, nr 4/2010, Amron, ZBP, grudzień 2010.

9. Ogólnopolski raport o kredytach mieszkaniowych $i$ cenach transakcyjnych nieruchomości, nr 4/2011, Amron, ZBP, luty 2012.

10. Ogólnopolski raport o kredytach mieszkaniowych $i$ cenach transakcyjnych nieruchomości, nr 1/2012, Amron, ZBP, maj 2012.

11. Sytuacja na rynku kredytowym. Wynik ankiety do przewodniczacych komitetów kredytowych. I kwartat 2012, NBP, Warszawa, styczeń 2012.

\section{Streszczenie}

Rynek kredytów hipotecznych w Polsce w ostatnich latach przeżywał dynamiczny rozwój. Kredyt stał się głównym źródłem finansowania nieruchomości, zwłaszcza nieruchomości mieszkaniowych, a jego dostępność znacznie wzrosła. Jednakże kryzys finansowy lat 2007-2009 spowodował konieczność zaostrzenia kryteriów oceny zdolności kredytowej. Celem niniejszej publikacji jest analiza wpływu zaostrzonych kryteriów zdolności kredytowej na liczbę zawieranych umów kredytów hipotecznych w Polsce. Autorzy badają również jak kształtować będzie się sytuacja na rynku kredytów hipotecznych w odniesieniu do roku 2020. 


\section{Summary}

\section{THE IMPACT OF INTENSIFYING THE CRITERIA OF PHYSICAL PERSONS' CREDITWORTHINESS ASSESSMENT ON THE NUMBER OF MORTGAGE AGREEMENTS}

The article considers the mortgage market in Poland, which has been affected by a rapid development in recent years. This type of loans have become the main source of real estate financing, especially for physical person. A widening group of customers could get a mortgage. However, the financial crisis of 2007-2009 made it necessary to tighten the criteria for creditworthiness assessment. This publication aims to analyze the impact of more stringent criteria for assessing the ability to contract a mortgage in Poland. 